\title{
Determinants of the Efficiencies in Turkish Banking Sector (Tobit Analysis)
}

\author{
Nizamülmülk Güneş ${ }^{1}$ \& Abdurrahman Yilmaz ${ }^{2}$ \\ ${ }^{1}$ Department of Audit, Savings Deposit Insurance Fund, Istanbul, Turkey \\ ${ }^{2}$ Department of Asset Management, Savings Deposit Insurance Fund, Istanbul, Turkey \\ Correspondence: Nizamülmülk Güneş, Tasarruf Mevduati Sigorta Fonu (TMSF), Denetim Dairesi, Buyukdere \\ Cd. No:143, Esentepe, Istanbul, 34394, Turkey. E-mail: nizamgunes@yahoo.com
}

Received: November 19, 2015

Accepted: December 17, 2015

Online Published: January 25, 2016

doi:10.5539/ijef.v8n2p215

URL: http://dx.doi.org/10.5539/ijef.v8n2p215

\begin{abstract}
The competition that has been faced in Turkish banking sector compels banks to use their sources efficiently. Efficiency and productivity analyses are important management tools to determine to what extent inputs have been used in the process of acquiring required outputs of banks. Efficient and productive functioning of the banks in Turkey has a major importance in terms of national economy. Being different from other economic sectors, the banking undertakes the duty of financial intermediation which determines resource allocation. This places banking to a central position for the economic development of the country. For this reason, analysis of efficiency and productivity measurements is necessary to carry out performance analysis of the banking sector.

This research aims at investigating the determinant factors of the technical, pure technical, and scale efficiencies of Turkish Banking Sector for the period of 2007-2013 with a sample of 4 Participation Banks (PBs) and 28 Conventional Deposit Banks (DBs) by using Tobit Regression Analysis.

The findings from Tobit regression analysis suggest that while the factors in terms of size, risk and bank management quality have negative impact on technical efficiency of Turkish banking sector, market share and profitability variables have positive impact. On the other hand, while the factors like market share, risk, bank management quality and year 2010 (as the dummy variable to capture the financial impact) have negative impact on pure technical efficiency, size and loan intensity have positive affect. Lastly, while the factors like size, risk and bank management quality is found affecting the scale efficiency negatively, loan intensity, market share and profitability variables have positive influence.
\end{abstract}

Keywords: tobit regression analysis, participation banks, deposit banks, efficiency on banking

\section{Introduction}

Performance evaluation of banking sector is significant for capital holders, investors, depositors and policy makers due to banks play a vital role in the formation and execution of resources allocation.

Within this context, banking is an over regulated sector by governments. It means that banks operate their functions in compliance with these frameworks. Banking sector is also enormously sensitive against economic changes that lead to the fragile side of the economy. Hence, from the regulators' perspective, inefficient banks are riskier and have more probability of failure. Further, the efficiency of banks is in relation with the productivity of the economy is an issue. Without a sound and efficiently performing banking system, the economy cannot perform smoothly and efficiently. When banking system fails, the whole payments system is negatively affected (Kumar \& Gulati, 2008). Therefore, the market structure needs to be analysed and regulated pursuant to the robust sustainability of the sector.

On the other hand, the globalization of financial markets and institutions along with the government deregulation, financial innovations, information revolution and advanced application in communication and technology, has created a competitive banking environment by changing the dynamics of the banking system (Srairi, 2010). Hence, it has been possible for banks to reach a great number of firms and individuals with the new financial instruments in markets. Due to these novelties in banking system, banks have tried to perform more efficiently in terms of cost and profit in order to be competitive (Karim \& Gee, 2007). 
It is clear that the capability of savings and their degree of conversion into investment are important for every economy. In this respect, financial intermediaries, especially banks, which are crucial and have to perform efficiently in order to sustain and improve their assets. On the contrary, decreasing efficiency or increasing inefficiency would affect adversely the dynamism of an economy in terms of productivity, employment, etc. It can be suggested that in a dynamic and open market environment, only efficient banks will survive and maintain their vitality due to their lower operational costs in financial markets, whilst inefficient ones will be sifted ultimately. In sum, the relative efficiency of banks always appeals the regulators', customers', stakeholders', and managers' interest (Kumar \& Gulati, 2008).

The existence of a sound banking system and the effectiveness of bank resources is important in terms of the financial system. Effective use of bank resources is the success of obtaining maximum output with a certain amount of input or the success of obtaining a certain amount of output with minimum input. The success covers both the production ability in appropriate scale and the managerial skills to manage the inputs.

The efficiency demonstrates the success of generating maximum possible output with inputs consumed. The success in the production of the highest possible output through using the input combination of the system in most suitable way is defined as "pure technical efficiency" and the success to produce the appropriate scale is defined as "scale efficiency". The efficiency calculated by multiplying the scale efficiency and technical efficiency is called as "technical efficiency". The theoretical developments related to the concept of efficiency has brought about the efforts to measure efficiency (Aydın, 2013). Competition in the Turkish banking sector forces banks to use their resources in the most effective manner. In order to achieve this, banks are required to assess their performance relatively in the sector in which they compete and to specify the source of efficiency/inefficiency of the factors affecting the performance.

Although there have been many international studies about the determinants of efficiency in the banking sector, it is difficult to say that a model which might be a reference for banking environment was able to be obtained. There is no doubt that the differences on the structure and properties of banking systems from country to country have an impact on this situation as much as the differences in the studied samples and analysis methods have. The most obvious differences between the studies are the period studied, the structure of sample (examination of a single banking system or multiple banking systems) or the method of analysis.

Effective and efficient operation of the banking sector has also great significance in Turkey as well as in the world due to banking sector assumes the financial intermediary role which determines the resource allocation unlike the other sectors, which makes the banking sector pivotal for economic growth. Hence, in order to be able to conduct performance analysis of banking sector, it is necessary to analyze the efficiency criteria (Aydogan \& Capoglu, 1989).

This study is different from other studies in terms of implementation period, method and the banks included in the sample. The study gives the basic size and shares in the system of participation and deposit banks but, in the analysis chapter, focuses on the determinants of sector as total through handling both participation and deposit banks together without any separation. Moreover, technical, pure technical and scale efficiency scores found by using data envelopment analysis (DEA) method named as "Efficiency Comparison of Participation and Conventional Banking Sectors in Turkey Between 2007 and 2013" were adopted as dependent variables and the relationship between independent variables and each of them was analyzed by Tobit method. Due to the discrete dependent variable, the Tobit model was preferred in the analysis. The study with this form is expected to contribute to literature.

The main aim of this paper is to examine the factors affecting efficiencies by using 'Tobit Regression Analysis'. Hence, the following research questions have been developed:

What is the general overview of participation or Islamic and conventional or deposit banking sectors in Turkey?

What are the determining factors of efficiency in these banks?

This paper is organized as follows: Section 2 provides an overview of the related studies in the literature; followed by Section; 3 which presents the development of the Turkish banking sector; Section 4 introduces the information about research data and methodology, lastly empirical findings and Section 5 concludes and offers avenues for future research.

\section{Literature Review}

Literature effectiveness measurement and Tobit models have been used frequently in many studies such as Ke-Chiun Chang et al. (2011); Anthony N. Rezitis (2006); Peter M. Jackson and Meryem D. Fethi (2000); Ilkka Susiluoto-Heikki A. Loikkan (2001); Serdar Kiliçkaplan and Gaye Karpat (2004); Abid A. Burki and Shabbir 
Ahmad (2010); Tze San Ong et al. (2011); John F. McDonald and Robert A. Moffitt (1980). Some studies on this subject in the world and Turkey are listed below.

Rezitis (2006) investigates productivity growth and technical efficiency in the Greek banking industry for the period 1982-1997. It also compares the 1982-92 and 1993-97 sub-periods, since 1992, after the Greek banking sector experienced substantial changes. The Malmquist productivity index and the DEA method are used to measure and decompose productivity growth and technical efficiency, respectively. Finally, Tobit analysis results show that size and specialization have positive effects on both pure and scale efficiency.

Kamaruddin et al. (2008) applied DEA for evaluating the cost and profit efficiencies of Malaysian Islamic banks and conventional bank Islamic windows for the period of 1998-2004. The results revealed that Islamic banks are more efficient than Islamic Windows in terms of costs but not at generating profits.

Burki and Ahmad (2010) examined the efficiency and performance of the banking system in Pakistan. Their sample consisted of 46 institutions in all. The study implemented the Stochastic Frontier Analysis as well as inefficiency cost analysis to examine the influence of their transformation from state-owned to foreign and private banks during 1991 to 2005 . The study also showed smaller banks were weaker and tended to engage in mergers and acquisitions as a way to increase their efficiency. The newly transformed private banks were found to be the most cost efficient, followed by foreign and state-owned ones. The study showed banks continue to improve their performance over the reform period.

Ong et al. (2011)'s analysis is based on a panel data set of 9 domestic banks and 12 foreign banks in Malaysia over the period of 2002-2009. The findings of the study show that domestic banks have a higher efficiency level than foreign banks. This implies that domestic banks are relatively more managerially efficient in controlling their cost. The second stage of the empirical results is based on Tobit model which suggests that the pure technical efficiency of banks in Malaysia is mainly affected by capital strength, loan quality, expenses and asset size.

Jackson and Fethi (2000) employed DEA and Tobit analysis to measure Turkish Banks technical efficiency for the year of 1998. They found that larger and profitable banks more likely to have ability to perform at higher levels of technical efficiency and the capital adequacy ratio has a statistically significant negative effect on the performance of Turkish banks.

Isik and Hassan (2003) analyzed the productivity growth, efficiency change and technical progress in Turkish commercial banks by employing DEA-Malmquist Total Productivity Change Index. They found that all forms of Turkish banks have succeeded significant productivity gains due to mainly efficiency increases rather than technical progress. On the other side, efficiency increases mostly depended on improved resource management practices instead of improved scales.

Yildirim (2002) investigated the efficiency of Turkish banking sector over the period of increasing macroeconomic instability between 1988 and 1999. The results revealed that over the sample period both pure technical and scale efficiency scores displayed a great alteration and the sector did not reach out the prolonged efficiency gains and the performance trend over the period demonstrated that macroeconomic conditions had a significant effect on the efficiency measures. The study also demonstrated that the sector was largely performing at decreasing return to scale.

El-Gamal and Inanoglu (2005) employed the stochastic frontier approach to determine the cost efficiency of Turkish banks over the period of 1990-2000. They compared the cost efficiencies of 49 conventional banks with four Islamic special finance houses (SFHs). Overall, they found that SFHs were the most efficient due to they perform on asset-based financing which causes lower non-performing loans ratios.

Bast (2005) the effects of the 2001 financial crisis on the productivity and efficiency of the Turkish banking sector is analyzed. The Malmquist Total Factor Productivity Index, constructed using nonparametric linear programming methods, is employed for the analysis. The empirical results show that the 2001 financial crisis negatively affected the productivity and efficiency of the Turkish banking sector.

Atan and Çatalbaş (2005) analyze the efficiency in banks according to capital structure by using data envelopment analysis (DEA) and whether there is a progress and intervention of banking groups during the period, December 2002 and September 2004. Furthermore, using Tobit regression it is assigned that Input-Output variables in DEA model are important in efficiency of banks or not.

Yayar and Karaca (2014) investigated efficiency of the banks carrying on their business in Turkey in 2009-2011 periods. Data Envelopment Analysis which is one of the non-parametric methods has been used to measure the efficiency. Moreover, factors that are considered as possible to affect efficiency scores of banks have been 
determined with Tobit regression analysis. Totally 37 banks data of which could be reached exactly have been included in the research. According to Tobit regression analysis results, total assets and profitability variables have a positive effect upon total efficiency scores, but capital adequacy ratio and number of branches have a negative effect.

Lastly, Güneş (2015) analyzed the data belonging to the period 2002-2012 of state-owned, privately owned national and foreign deposit banks operating in Turkish banking sector by using stata program and panel data method. The analysis results indicate that capital is the most important variables for ROA and ROE. It is also concluded that growth for benefitting from the advantages of scale economy, keeping non-performing loans low and inflation expectations have positive effect on profitability.

\section{Development of the Turkish Banking Sector}

The capability of savings and the degree of canalizing into investment are also important for Turkey. Therefore, in addition to conventional banks, as equivalent of Islamic banks, Participation banks are also in a critical position and have to perform efficiently in order to sustain and improve their assets. Therefore, the indicators and determinants of efficiency should also be identified and observed closely in the Turkish PBs and DBs.

Looking at the banking reforms in Turkey, new Banking Act of 1 November 2005 distinguishes banks into three subdivisions: Deposit banks, Participation (Islamic) banks, and Development and Investment banks pursuant to the type of operation they conduct. By the end of 2013, there exist 49 banks (including foreign banks) in operation totally - 32 deposit banks, 13 investment banks and 4 participation banks (TBB, 2014). Seven large banks (deposit banks) represent $75,3 \%$ of the entire banking industry show that Deposit banking is mainstream (Thomson Reuters, 2013).

Table 1. Deposits development of PNs and DBs between 2007-2013 years

\begin{tabular}{ccccccccc}
\hline Year & $\begin{array}{c}\text { Deposits of Total } \\
\text { Banking } \\
\text { Industry \% }\end{array}$ & $\begin{array}{c}\text { Deposits Growth } \\
\text { of Total Banking } \\
\text { Industry \% }\end{array}$ & $\begin{array}{c}\text { Deposits of } \\
\text { PBS } \\
\text { (USD-million) }\end{array}$ & $\begin{array}{c}\text { Deposits } \\
\text { Growth of } \\
\text { PBS \% }\end{array}$ & $\begin{array}{c}\text { Share of PBS in } \\
\text { Total Banking } \\
\text { Industry \% }\end{array}$ & $\begin{array}{c}\text { Deposits of } \\
\text { DBS } \\
\text { (USD-million) }\end{array}$ & $\begin{array}{c}\text { Deposits } \\
\text { Growth of } \\
\text { DBS \% }\end{array}$ & $\begin{array}{c}\text { Share of DBS in } \\
\text { Total Banking } \\
\text { Industry \% }\end{array}$ \\
\hline 2007 & 307.169 & & 12.732 & & 4,1 & 294.437 & & 95,9 \\
2008 & 299.168 & $-2,6$ & 12.552 & $-1,4$ & 4,2 & 286.616 & $-2,7$ & 95,8 \\
2009 & 345.589 & 15,5 & 17.766 & 41,5 & 5,1 & 327.823 & 14,4 & 94,9 \\
2010 & 402.444 & 16,5 & 21.436 & 20,7 & 5,3 & 381.008 & 16,2 & 94,7 \\
2011 & 370.346 & $-8,0$ & 20.620 & $-3,8$ & 5,6 & 349.726 & $-8,2$ & 94,4 \\
2012 & 435.662 & 17,6 & 26.900 & 30,5 & 6,2 & 408.762 & 16,9 & 93,8 \\
2013 & 444.550 & 2,0 & 28.728 & 6,8 & 6,5 & 415.821 & 1,7 & 93,5 \\
\hline
\end{tabular}

Table 1 depicts the trends of deposits held by the PBs and DBs, and their shares in whole banking system. For example, the growth of the deposits for PBs reached peak point in 2009 with $41,5 \%$; the same performance cannot be shown again. The lowest growth rate in the period covered was $-3,8 \%$ in 2011 . Table 1. also points outs that PBs have been more successful over the years in terms of deposits growth rates compared to DBs. However, the share of PBs in the total banking sector has been a little more better by reaching 6,5\% in 2013, but too far and low for Turkey's potential.

Looking at the sector's asset composition in order to analyse PBs and DBs activities, PBs have more stable and significantly higher share of loans to total assets compared to DBs, even though that ratio begins to increase gradually for DBs starting with 2010. However, PBs almost do not have any securities in their portfolio due to the absence of shari'ah compliant securities in Turkey, however, as stated above due to emerging legislative infrastructure regarding capital market oriented products and investments, PBs' share is at infancy age starting from 2009. On the other hand, DBs hold securities portfolio as a serious rate of its assets despite the securities gradually decreased starting from 2009. Fixed assets to total assets of both sector represent negligible shares between the range of $1,1 \%$ and $3,2 \%$ of total assets, which reflects a high liquidity that mitigates risks in these sectors. In relation to total equity to total liabilities, there is no significant difference between two sectors and both sectors' assets are financed by liabilities between the range of $87 \%$ and $91 \%$. 
Table 2. Ratios related banking operations

\begin{tabular}{|c|c|c|c|c|c|c|c|c|c|c|c|c|c|c|}
\hline \multirow{2}{*}{$\%$} & \multicolumn{2}{|c|}{2007} & \multicolumn{2}{|c|}{2008} & \multicolumn{2}{|c|}{2009} & \multicolumn{2}{|c|}{2010} & \multicolumn{2}{|c|}{2011} & \multicolumn{2}{|c|}{2012} & \multicolumn{2}{|c|}{2013} \\
\hline & PBS & DBS & PBS & DBS & PBS & DBS & PBS & DBS & PBS & DBS & PBS & DBS & PBS & DBS \\
\hline Loans / Total Asset & 72 & 48 & 68 & 50 & 70 & 46 & 71 & 51 & 69 & 56 & 68 & 57 & 65 & 60 \\
\hline $\begin{array}{c}\text { Credit Growth } \\
\text { Rate }\end{array}$ & 82,7 & 56,7 & $-3,7$ & $-1,5$ & 35,2 & 7,2 & 27 & 30,9 & 1,5 & 5,9 & 32,9 & 22,1 & 7,9 & 9,3 \\
\hline $\begin{array}{c}\text { Securities / Total } \\
\text { Asset }\end{array}$ & 0,1 & 29,8 & 0,1 & 28 & 3,1 & 33,4 & 3,3 & 30,2 & 3,5 & 24,8 & 3,5 & 21 & 5 & 17,7 \\
\hline $\begin{array}{l}\text { Fixed Assets / } \\
\text { Total Assets }\end{array}$ & 2,1 & 2,8 & 3,1 & 2,6 & 3,2 & 2,5 & 2 & 1,9 & 2,1 & 1,4 & 2,4 & 1,3 & 2 & 1,1 \\
\hline $\begin{array}{l}\text { Liabilities / Total } \\
\text { Liabilities }\end{array}$ & 88 & 88 & 86 & 89 & 87 & 88 & 87 & 88 & 89 & 89 & 90 & 87 & 91 & 89 \\
\hline $\begin{array}{l}\text { Total Equity / Total } \\
\text { Liabilities }\end{array}$ & 12 & 12 & 14 & 11 & 13 & 12 & 13 & 12 & 11 & 11 & 10 & 13 & 9 & 11 \\
\hline $\begin{array}{c}\text { Total Loans / Total } \\
\text { Deposits }\end{array}$ & 103,8 & 79,6 & 100 & 80,6 & 94,1 & 77 & 97,2 & 85,2 & 102,7 & 97,3 & 104,9 & 101,9 & 107,9 & 109,3 \\
\hline
\end{tabular}

In order to analyse the impact of the banks on the economy, PBs' loans to deposit ratio demonstrates higher positive impact of on the real economy in comparison to DBS. As can be seen, this ratio, which shows the given credit to the real sector for PBS, has always been higher for PBs as compared to DBs over the period with the exception of 2013.

\section{Modelling, Data and Methodology}

\subsection{Tobit as a Method of Analysis}

Tobit Regression Analysis is employed to investigate the determinant factors of efficiencies. We used DEA Solver Professional Version 5.0 to obtain efficiency scores, while using Stata 12.0 Statistics Data Analysis Program for Tobit Regression.

Tobit Model which is an extension of Probit Model, is developed by James Tobin. A sample in which information on the dependent variable is ready merely for some observations is known as a censored sample. Hence, the Tobit Model is known as a censored or limited dependent variable regression model as well (Gujarati, 2003).
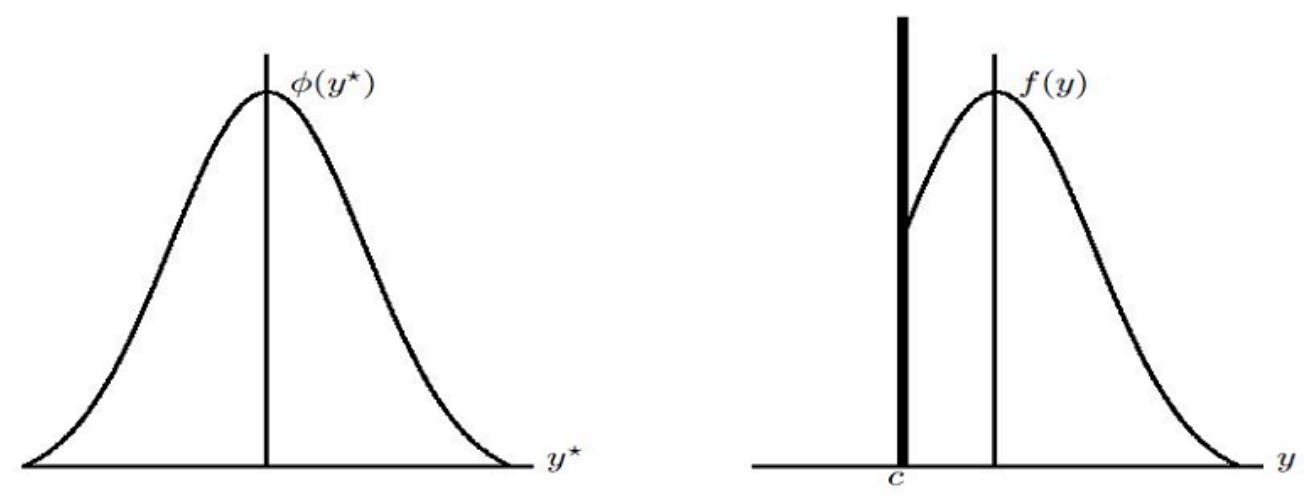

Figure 1. (Normal variable $\mathrm{y}^{*}$ and Censored variable y)

Source: http://www.ssicentral.com/lisrel/techdocs/censor.pdf.

Tobit Model is an alternative of non-parametric least squares regression (Liao, 1994). Due to the Tobit model is an extension of Probit Model, it is derived from the names of Tobin and Probit (Rajulton, 2011). Existence of a latent $y^{*}$ variable is accepted as in partial regression model. That variable is tied to xi independent variable with parameters vector. The concentration of new random variable which is obtained thereby converting from original random variable and has c point as censor point in Censored model is depicted as below (Jöreskog, 2002).

The standard Tobit model can be defined as follows for observation (bank): 


$$
y_{i}^{*}=\beta^{\prime} x_{i}+\varepsilon_{i}, \quad y_{i}=y_{i}^{*} \quad \text { if } y_{i}^{*} \geq 0 \text { and } y_{i}=0 \text {, otherwise }
$$

Where $\varepsilon_{\mathrm{i}} \sim \mathrm{N}\left(0, \sigma^{2}\right)^{3}$, xi and $\beta$ are vectors of explanatory variables and unknown parameters, respectively. The $\mathrm{y}_{\mathrm{i}}^{*}$ is a latent variable and yi is the DEA score.

The likelihood function (L) is maximized to solve $\beta$ and $\sigma$ based on 32 observations (banks) of $y_{i}$ and xi is:

$$
\begin{gathered}
L=\prod_{y_{i=0}}\left(1-F_{i}\right) \quad \prod_{y_{i>0}} \frac{1}{\left(2 \prod \sigma^{2}\right)^{1 / 2}} X e^{-\left[1 /\left(2 \sigma^{2}\right)\right]\left(y_{i}-\beta x_{i}\right)^{2}} \\
F_{i}=\int_{-\infty}^{\beta x_{i}} \frac{1}{(2 \Pi)^{1 / 2}} e^{-t^{2} / 2} d t
\end{gathered}
$$

The first product is over the observations for which the banks are $100 \%$ efficient $(y=0)$ and the second product is over the observations for which banks are inefficient $(\mathrm{y}>0)$. Fi is the distribution function of the standard normal evaluated at $\beta^{\prime} x i / \sigma$.

Using the efficiency scores as the dependent variable, we estimate the following regression model:

$$
\text { BANKEFF }_{j t}=\alpha+\beta_{1} \text { SBank_Characteristics }+\beta_{2} \text { Macroeconomic } \text { Conditions }_{-}+\beta_{3} \text { Islamic_Banks }_{-} \varepsilon
$$

where, BANKEFFjt is the TE, PTE and SE of the PBs and DBs in period t obtained from DEA, Bank_Charateristics is an array of bank specific trait variables, Islamic_Banks or PBs is a dummy variable that takes a value of 1 for Islamic banks, 0 otherwise, and Macroeconomic Conditions is a vector of macroeconomic variables.

In order to avoid the negative effects of the global financial crisis beginning in 2008 and lasted until 2011 on the analysis, dummy was used for the years of 2008, 2009, 2010 and 2011.

\subsection{Definition and the Choice of Variables}

From the study of "Efficiency Comparison of Participation and Conventional Banking Sectors in Turkey Between 2007-2013" dated 3 rd. July 2015, the results of efficiency analysis were found by using data envelopment analysis (DEA) (Yilmaz \& Gunes: 2015). These results were assessed as dependent variable in this study. In this context, it focused on factors which determine the values of efficiency. Technical, pure technical and scale efficiencies were approached as dependent variables and the determiners of efficiencies were analyzed by Tobit regression model. In order not to fall into repetition, DEA analysis results were not used in this study, DEA results were used in Tobit analysis.

In the regression models in which the variation range of dependent variable is limited in any way, the subject will be the discrete model if the observations outside of a certain range are completely lost but the subject will be censored regression models if at least the independent variables are observed. Because of this aspect, Tobit Model was selected as the research method.

Owing to the entry and exit factor, the efficiency frontier is constructed by using an unbalanced sample of 4 PBs and 28 DBs which have operated in Turkey throughout the period 2007-2013, yielding 224 bank year observations. Data for the empirical analysis is sourced from The Banks Association of Turkey (TBB) as well as individual bank's annual balance sheet and income statements.

The efficiency scores of banks regarding technical, pure technical and scale efficiencies obtained through using DEA by Yilmaz and Güneş (2015) constitute dependent variable in this study. In relation to independent variables, we consider the total loans to bank total assets (LOANSTA) as the measure of bank's loans intensity; bank's total asset to PBS/DBS's total assets (LNTA) as the measure of size; bank's total deposits to PBS/DBS's total deposits (LNDEPO) as the measure of bank's market share; total loan loss provisions to total loans (LLP/TL) as the measure of banks risk; total non-interest expenses to total assets (NIE/TA) as the measure of bank management quality; banks' total shareholders equity to total assets (EQASS) as the measure of bank leverage intensity; bank profit after tax to total assets (ROA) as the measure of bank profitability. DUMISLAMIC is a dummy variable which takes a value of 1 for Islamic banks, 0 otherwise; DUM2008, DUM2009, DUM2010 and DUM2011 are dummy variables that take a value of 1 for years 2008, 2009, 2010 and 2011, respectively, 0 otherwise. Our all findings are between the $95 \%$ confidence interval in this study.

Tobit regression results focusing on the relationship between bank efficiency (technical, pure technical and scale efficiency scores derived from DEA) and the explanatory variables are presented in Table 1,2 and 3 . The equations are based on 224 bank year observations during the 2007-2013 period. First, we suggest a number of potential determinants and then continue to discuss the empirical results. 


\subsection{Analyses and Results}

We initially consider the effects of these variables on technical efficiency. Table 1 reports the results of Tobit analysis with regard to TE. Thus, as the measure of loans intensity, LOANS/TA reveals positive relationship with banks' TE levels. However, it is statistically insignificant. Nevertheless, findings seem to suggest that banks with higher loans-to-asset ratio tend to exhibit higher TE levels. Isik and Hassan (2003) argue that the positive relationship between loan activity and bank efficiency may be due to the fact that relatively efficient banks have capability for managing operations more productively. So they have lower production costs and are able to offer more reasonable loan terms and that makes them gain larger market shares in loan market.

The findings relating to bank's size, LNTA shows negative and significant coefficients, suggesting that the larger banks tend to be less efficient because of the prevailing DRS arguments in Turkish banking sector. As the measure for market power, LNDEPO reveals positive relationship with bank efficiency and suggesting that the more efficient banks are associated with the banks with higher market share.

As a proxy of risk, as expected, LLP/TL exhibits negative relationship with bank TE, indicating increase in inefficiency. The finding is consistent with earlier findings of Barr et al. (2002), who found negative relationship between non-performing loans and banks' TE. The results imply that the banks should concentrate more on credit risk management.

Findings relating to total non-interest expenses to total assets (NIE/TA) as the measure of bank management quality also exhibit negative relationship with banks' TE, indicating increase in inefficiency. That is consistent with Claessens et al. (2001) who argues that overstaffing may lead to the deterioration of banks' TE levels in the middle-income countries.

As the measure of bank leverage intensity, EQASS seems to exhibit negative relationship with the TE, however, statistically insignificant. Negative relationship implies that banks with higher EQASS are less efficient since they are risk-averse and prefer safer and lower-earning portfolios (Jackson \& Fethi, 2000). Finally, as the measure of bank profitability, ROA exhibits positive relationship with bank TE, indicating that the more efficient banks tend to be more profitable as expected.

Among others, Berger et al. (1995) suggests that different banking forms could demonstrate different reactions to environmental changes. Hence, the change in the financial landscape and structure, etc. may vary across banking groups. For this, as a robustness check, a binary dummy variable DUMISLAMIC takes a value of 1 for Islamic banks and 0 otherwise. DUMISLAMIC exhibits positive relationship with the TE, implying that the Islamic banks are relatively more efficient compared to DBs with statistically significance. The finding is consistent with our earlier findings that the PBs $(0,845)$ are more efficient than the DBs $(0,816)$ in terms of TE.

To be able to capture the developments in regulatory environment and marketplace especially after 2008 global crises, since the world conventional and Islamic banking industry has encountered serious structural change, this study analyzes the efficiency of the Turkish PBS and DBS together at different points of time. Therefore, as a final check, dummy variables for each year, DUM2008, DUM2009, DUM2010, and DUM2011 are used to take into account the changes in the banking sector environments during the period.

Since TE can be decomposed into PTE and SE, Table 2 and Table 3 presents the empirical results of the determinants of PTE and SE, respectively, which suggest that all the yearly dummy variables are positively related to bank's TE, PTE and SE with the exception of year 2010 which is statistically only consistent for PTE. In other words, negative effects of global crises might have taken place in 2010 in Turkish banking sector.

As can be seen at Table 2, while Tobit regression results for PTE with regard to LOANSTA, LLP/TL, NIE/TA, EQASS, ROA and DUM2008, DUM2009, DUM2010 and DUM2011 seem to have the same effects with the Tobit regression for TE, while LNTA as the measure of size, LNDEPO as the measure of bank's market share and DUMISLAMIC variables differ from the results of Tobit regression for TE. 
Table 3. Tobit regression results for PBs' and DBs' TE in Turkey

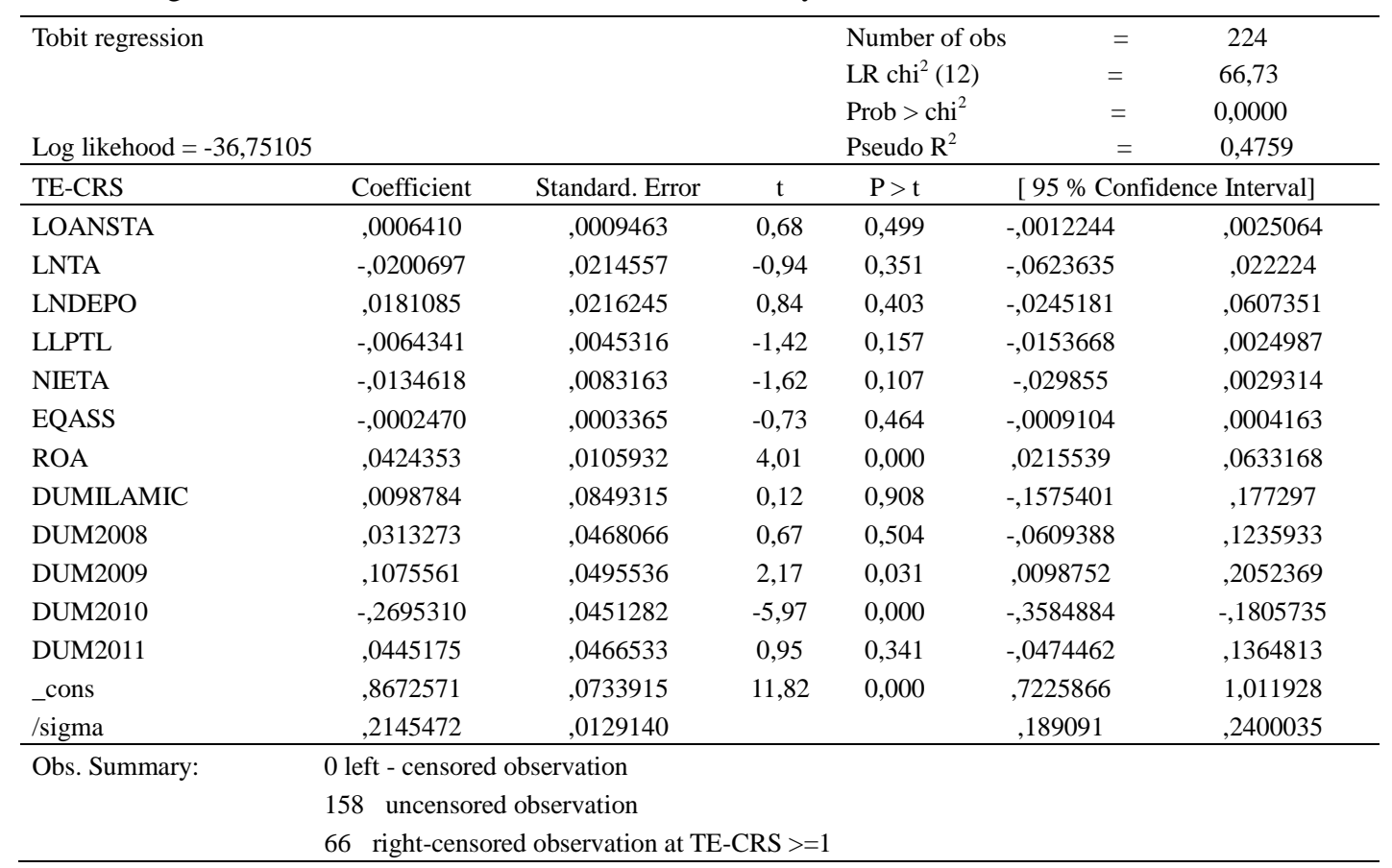

LNTA shows positive and significant coefficients that means LNTA has positive effect on PTE and the larger banks tend to be more efficient due to the management of the bigger banks were more efficient in converting their inputs into outputs regardless of their scale in Turkish banking sector and this finding is supported by many previous studies (for instance Hauner, 2005; Hassan, 2006).

LNDEPO shows negative relationship with bank PTE, which suggest that more efficient banks tend to be the banks with smaller market share, and these banks can be as efficient as the market leader banks due to preserving or broadening market share may entail extra costs and inputs.

As for DUMISLAMIC, it exhibits a negative relationship with the PTE, however, statistically insignificant.

Table 4. Tobit regression results for PBs' and DB's PTE in Turkey

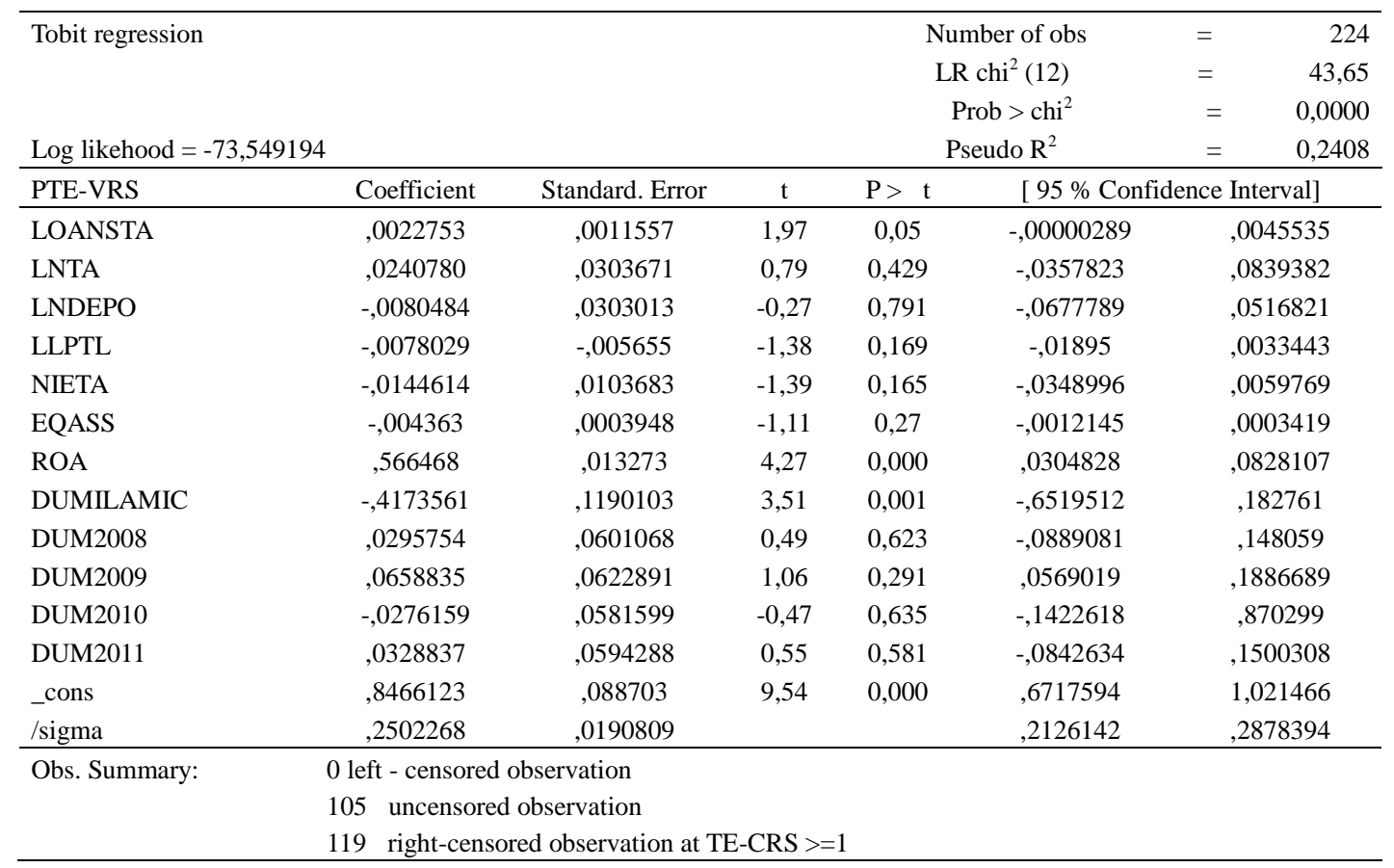


As can be seen in Table 3, while Tobit regression results for SE with regard to LOANSTA, LLP/TL, NIE/TA, ROA, DUMISLAMIC and DUM2008, DUM2009, DUM2010 and DUM2011 seem to have the same affects with the Tobit regression for TE, while EQASS as the measure of bank leverage intensity differs from the results of Tobit regression for TE.

EQASS seems to exhibit positive relationship with bank SE levels although the effect is not significant.

Table 5. Tobit regression results for PBs' and DBs' SE in Turkey

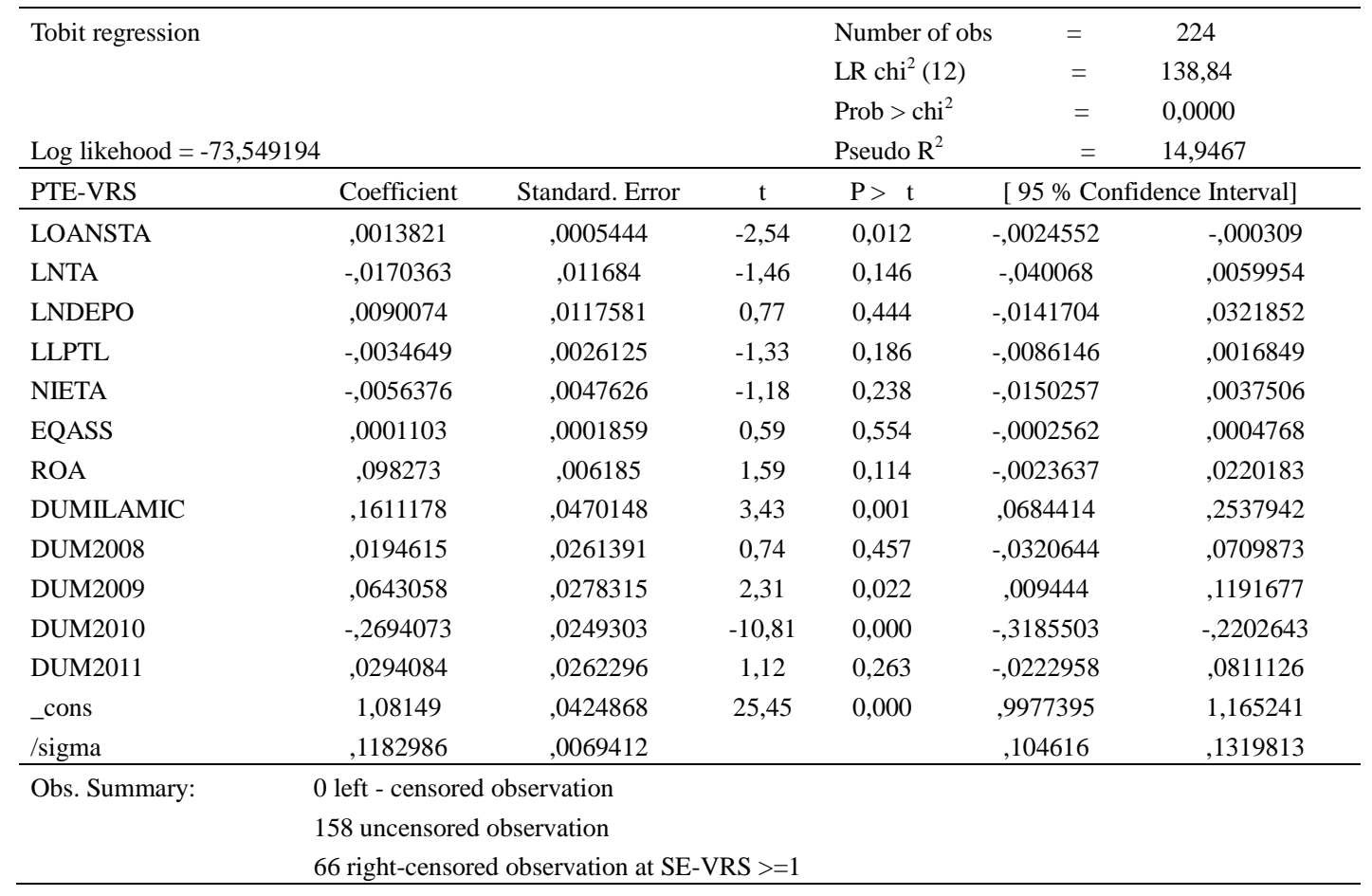

\section{Conclusion}

Banks are one of the most important factors that direct the economy of a country. After 2001 economic crisis, financial sector in Turkey has entered into the process of reconstruction. New legal regulations have been brought for the banks. Recently, banking sector has ranked first among the leading factors of economic crisis. For this reason, banks' efficient use of their sources has been quite important in terms of steady economic growth and development.

This study deals technical, pure technical and scale efficiencies as dependent variables and analyzes the efficiency determiners of 4 Participation Banks and 28 Conventional Deposit Banks operating in Turkey between 2007 and 2013 by Tobit regression model.

The results of Tobit regression analysis suggest that while the factors in terms of size, risk and bank management quality have negative impact on TE of Turkish banking sector, market share and profitability have positive impact.

On the other hand, while the factors like market share, risk, bank management quality and year 2010 have negative impact on PTE, size and loan intensity have positive affect.

Lastly, while the factors like size, risk and bank management quality affects the SE negatively, loan intensity, market share and profitability variables have positive influence.

In its entirety, the study reveals that there is a broad scope for enhancement in the performance of both inefficient PBs and DBs by selecting a correct input-output mix and preferring appropriate scale size.

It seems that Turkey does have the necessary motivation and potential to become as one of the pioneer Islamic and conventional financial centre in the world by taking more International capital inflow. Owing to this, detailed examination of indicators and the determinants of efficiency in both PBS and DBS might be useful for researchers and third parts. 
The constraints of this study include the data of the years 2007-2013 through utilizing 8 financial ratios of participation and conventional banks. The future studies including longer periods, more banks and financial ratios can be compared with the results of this study. In addition to this, in the future studies banks can be divided into four groups as participation banks, private banks, foreign banks and public banks and the financial performance of the banks in question can be measured and compared.

\section{References}

Atan, M., \& Çatalbaş, G. K. (2005). Bankacılıkta Etkinlik ve Sermaye Yapısının Bankaların Etkinliğine Etkisi. Iktisat Issletme ve Finans, 20(237), 63-79.

Aydın, Ü. (2013). Türkiye'deki Yatıım Fonlarının Performanslarının Değerlendirilmesi: DEA ve Tobit Model Uygulamas1. Marmara Üniversitesi İIBF Dergisi, 34(1), 87-110.

Aydoğan K., \& Çapoğlu, G. (1989). Bankacıllk Sistemlerinde Etkinlik ve Verimlilik: Uluslararası Bir Karşılaştırma. Ankara: Milli Prodüktivite Merkezi Yayınları.

Bast1, E. (2005). 2001 Finansal Krizinin Türkiye Ticari Bankacılık Sektörünün Toplam Faktör Verimliliğine Etkileri. İktisat İsletme ve Finans, 20(237), 63-79. http://dx.doi.org/10.3848/iif.2005.237.9220

Berger, A. N., Kashyap, A. K., \& Scalise, J. M. (1995). The Transformation of the US Banking Industry: What a Long, Strange Trip it's Been. Brookings Papers on Economic Activity, 2, 55-218. http://dx.doi.org/10.2307/2534612

Burki, A., \& Ahmad, S. (2010). Bank Governance Changes in Pakistan: Is There a Performance Effect? Journal of Economics and Business, 62(2), 129-146. http://dx.doi.org/10.1016/j.jeconbus.2009.08.002

Claessens, S., Dermiguc-Kunt, A., \& Huizinga, H. (2001). How Does Foreign Presence Affect Domestic Banking Markets? Journal of Banking \& Finance, 25(5), 891-911. http://dx.doi.org/10.1016/S0378-4266(00)00102-3

El-Gamal, M., \& Inanoglu, H. (2005). Inefficiency and Heterogeneity in Turkish Banking: 1990-2000. Journal of Applied Econometrics, 20(5), 641-664. http://dx.doi.org/10.1002/jae.835

Gujarati, D. N. (2003). Basic Econometrics. New York, NY: McGraw-Hill.

Gunes, N. (2015). Banka Kârlılı̆̆ının Belirleyicileri: 2002-2012 Dönemi Türk Mevduat Bankaları Üzerine bir İnceleme. Süleyman Demirel Üniversitesi IİBF Dergisi, 20(3), 265-282.

Isik, I., \& Hassan, M. K. (2003). Financial Deregulation and Total Factor Productivity Change: An Empirical Study of Turkish Commercial Banks. Journal of Banking \& Finance, 27(8), 1455-1485. http://dx.doi.org/10.1016/S0378-4266(02)00288-1

Jackson, P. M., \& Fethi, M. D. (2000). Evaluating the Technical Efficiency of Turkish Commercial Banks: An Application of DEA and Tobit Analysis. The International DEA Symposium, University of Queensland, Australia.

Jöreskog, G. K. (2002). Censored Variables and Censored Regression. Retrieved from http://www.ssicentral.com/lisrel/techdocs/censor.pdf

Kamaruddin, B. H., Safa, M. S., \& Rohani, M. (2008). Assessing Production Efficiency of Islamic Banks and Conventional Banks Islamic Windows in Malaysia. International Journal of Business and Management Sciences, 1(1), 31-48.

Karim, M. Z., \& Gee, C. S. (2007). Off-Balance Sheet Activities and Performance of Commercial Banks in Malaysia. The IUP Journal of Financial Economics, (4), 67-80.

Kumar, S., \& Gulati, R. (2008). An Examination of Technical, Pure Technical, and Scale Efficiencies in Indian Public Sector Banks using Data Envelopment Analysis. Eurasian Journal of Business and Economics, 1(2), 33-69.

Liao, T. F. (1994). Interpreting Probability Models Logit, Probit, and Other Generalized Linear Models. Cincinnati: Sage University Paper.

Ong, T. S., Lim, Y. T., \& Teh, B. H. (2011). A Comparison on Efficiency of Domestic and Foreign Banks in Malaysia: A DEA Approach. Business Management Dynamics, 1(4), 33-49.

Rajulton, F. (2011). Logit, Probit and Tobit Models for Categorical and Limited Dependent Variables. Retrieved from http://rdc.uwo.ca/./docs/presentation_slides/2010-11/Fernando-Logit2011.pdf 
Rezitis, A. N. (2006). Productivity Growth in the Greek Banking Industry: A Non-Parametric Approach. Journal of Applied Economics, IX(1), 119-138.

Srairi, S. A. (2010). Cost and Profit Efficiency of Conventional and Islamic Banks in GCC Countries. Journal of Productivity Analysis, Springer, 34(1), 45-62. http://dx.doi.org/10.1007/s11123-009-0161-7

Thomson Reuters. (2013). Turkey Islamic Finance Report 2014: Fundamentals and the Promise of Growth.

Turkiye Bankalar Birligi (TBB). (2014). Bankalarimiz 2013. Istanbul: Yayin No: 304.

Yayar, R., \& Karaca, S. S. (2014). Efficiency Analysis in Turkish Banking Sector. Niğde Üniversitesi İ̈BF Dergisi, 7(2), 1-15.

Yildirim, C. (2002). Evolution of banking Efficiency within an Unstable Macroeconomic Environment: The Case of Turkish Commercial Banking. Applied Economics, 34(18), 2289-2301. http://dx.doi.org/10.1080/00036840210140146

Yilmaz, A., \& Güneş, N. (2015). Efficiency Comparison of Participation and Conventional Banking Sectors in Turkey between 2007-2013. Procedia-Social and Behavioral Sciences, 195, 383-392. http://dx.doi.org/10.1016/j.sbspro.2015.06.338

\section{Copyrights}

Copyright for this article is retained by the author(s), with first publication rights granted to the journal.

This is an open-access article distributed under the terms and conditions of the Creative Commons Attribution license (http://creativecommons.org/licenses/by/3.0/). 